\title{
Anticancer Effects of Geopropolis Produced by Stingless Bees on Canine Osteosarcoma Cells In Vitro
}

\author{
Naiara Costa Cinegaglia, ${ }^{1}$ Paulo Ricardo Oliveira Bersano, ${ }^{2}$ \\ Maria José Abigail Mendes Araújo, ${ }^{3}$ Michelle Cristiane Búfalo, ${ }^{3}$ and José Maurício Sforcin ${ }^{3}$ \\ ${ }^{1}$ Surgery and Orthopedics Department, Medical School, São Paulo State University (UNESP), 18618-970 Botucatu, SP, Brazil \\ ${ }^{2}$ Investigative and Comparative Pathology Laboratory, College of Veterinary Medicine and Animal Husbandry, \\ São Paulo State University (UNESP), 18618-970 Botucatu, SP, Brazil \\ ${ }^{3}$ Department of Microbiology and Immunology, Biosciences Institute, São Paulo State University (UNESP), \\ 18618-970 Botucatu, SP, Brazil
}

Correspondence should be addressed to José Maurício Sforcin; sforcin@ibb.unesp.br

Received 2 January 2013; Revised 28 March 2013; Accepted 1 April 2013

Academic Editor: Ewelina Szliszka

Copyright (c) 2013 Naiara Costa Cinegaglia et al. This is an open access article distributed under the Creative Commons Attribution License, which permits unrestricted use, distribution, and reproduction in any medium, provided the original work is properly cited.

Geopropolis is produced by indigenous stingless bees from the resinous material of plants, adding soil or clay. Its biological properties have not been investigated, such as propolis, and herein its cytotoxic action on canine osteosarcoma (OSA) cells was evaluated. OSA is a primary bone neoplasm diagnosed in dogs being an excellent model in vivo to study human OSA. spOS2 primary cultures were isolated from the tumor of a dog with osteosarcoma and incubated with geopropolis, $70 \%$ ethanol (geopropolis solvent), and carboplatin after 6, 24, 48, and 72 hours. Cell viability was analyzed by the crystal violet method. Geopropolis was efficient against canine OSA cells in a dose- and time-dependent way, leading to a distinct morphology compared to control. Geopropolis cytotoxic action was exclusively due to its constituents since $70 \%$ ethanol (its solvent) had no effect on cell viability. Carboplatin had no effect on OSA cells. Geopropolis exerted a cytotoxic effect on canine osteosarcoma, and its introduction as a possible therapeutic agent in vivo could be investigated, providing a new contribution to OSA treatment.

\section{Introduction}

Propolis is a resinous material collected by bees from buds and exudates of the plants and mixed with wax and bee enzymes. It is composed in natura of $30 \%$ wax bee, $50 \%$ resins and vegetable balsams, $10 \%$ essential oils, $5 \%$ pollen, and $5 \%$ other substances $[1,2]$. Contrarily, indigenous stingless bees such as Melipona fasciculata Smith collect resinous material of plants and add soil or clay, forming the so-called "geopropolis" [3, 4].

Although propolis pharmacological activities have been extensively reported [5], few articles have investigated the geopropolis biological action. The antimicrobial activity of geopropolis produced by Melipona compressipes fasciculate was analyzed, and its hydroalcoholic extract decreased to $48.5 \%$ the number of colonies of Streptococcus mutans in saliva of patients [6]. The anti-inflammatory, antinociceptive, and antitumor activities of geopropolis have also been reported $[7,8]$.

The activity of geopropolis (extracts and gel) against oral pathogens and on S. mutans biofilms was investigated [9]. Geopropolis collected in Palmeirândia, State of Maranhão, Brazil, displayed antimicrobial activities; in addition, a geopropolis-based gel was not toxic in an animal model and showed anti-inflammatory effects. Phenolic compounds, triterpenes, and saponins were found in its chemical composition, which may vary according to the local flora [10].

Several researchers have reported the antitumoral property of propolis both in vitro and in vivo [11], but little is known concerning geopropolis cytotoxic action towards tumor cells. Osteosarcoma (OSA) or osteogenic sarcoma originated from the central or spinal skeleton is considered the most common and malignant skeletal neoplasm in dogs $[12,13]$ and is a neoplasm frequently diagnosed in dogs [14]. 


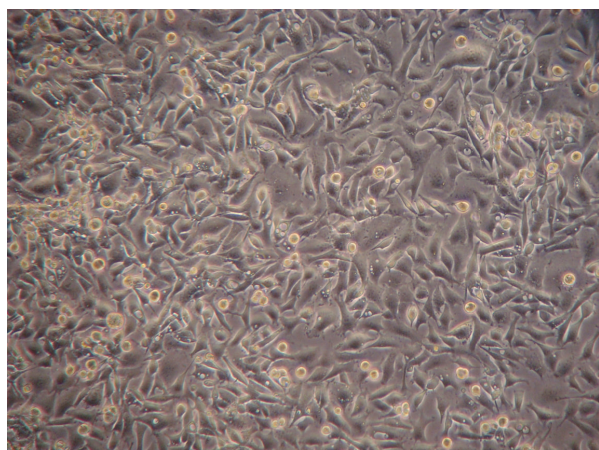

(a)

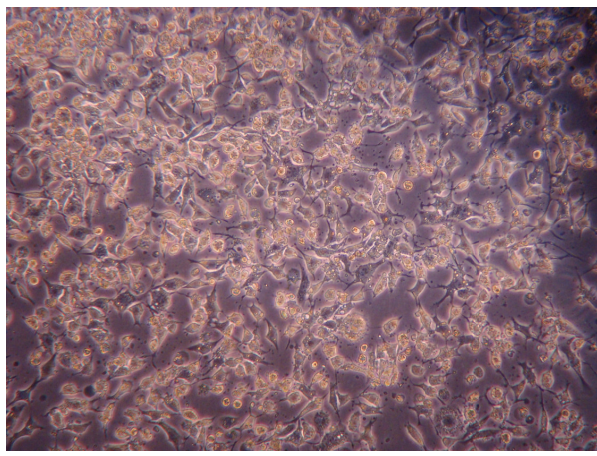

(c)

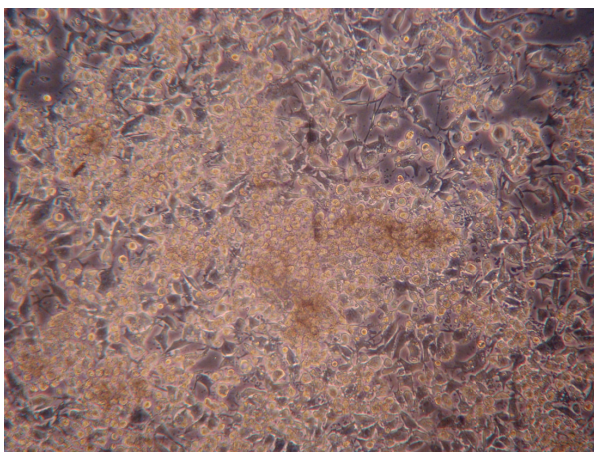

(e)

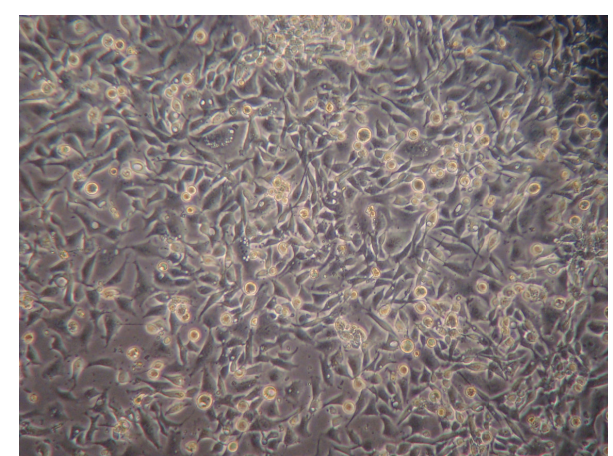

(b)

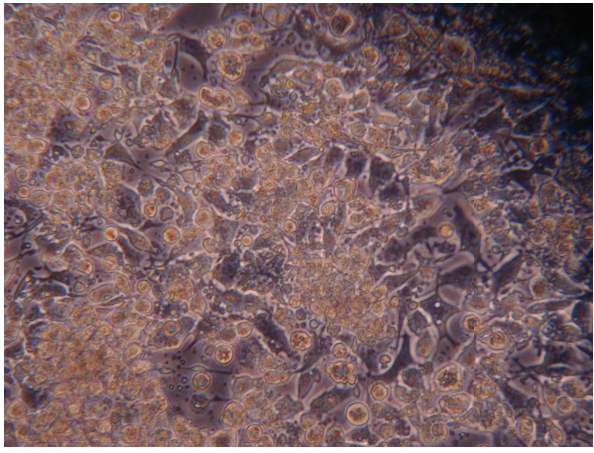

(d)

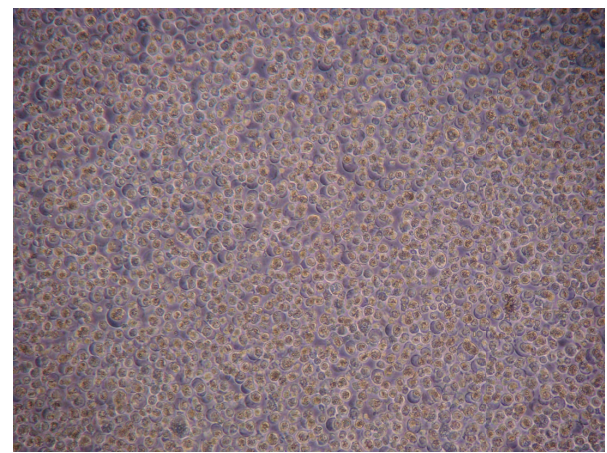

(f)

Figure 1: Canine OSA cells (100-fold increase). (a) Control; (b) 70\% ethanol; (c) geopropolis $6 \mathrm{~h}, 50 \mu \mathrm{g}$; (d) geopropolis $24 \mathrm{~h}$, $50 \mu \mathrm{g}$; (e) geopropolis $48 \mathrm{~h}, 10 \mu \mathrm{g}$; (f) geopropolis $72 \mathrm{~h}, 10 \mu \mathrm{g}$. Data represent three similar assays.

The behavior of OSA in pet dogs is identical to that of pediatric patients, and it has been considered an excellent model in vivo to study human OSA [15-17]. Carboplatin, cisplatin, and doxorubicin are chemotherapeutic agents used to induce remission of the tumor and as a maintenance therapy as well. However, the outcome of chemotherapy in dogs is unpredictable and may not respond to the action of cytotoxic drugs $[18,19]$.

Since geopropolis possesses several biological properties, we evaluated a possible antitumor action of geopropolis in vitro, using OSA cells and different geopropolis concentrations along different periods of time.

\section{Materials and Methods}

2.1. Geopropolis Sample. Geopropolis was produced by Melipona fasciculata Smith and was aseptically collected in Palmeirândia, Western Maranhão State, where municipalities are formed by different ecosystems such as mangroves, flooded fields, ponds, forests, and babassu [20].

Samples were ground, and 30\% ethanolic extracts of geopropolis were prepared ( $80 \mathrm{~g}$ of geopropolis, completing the volume to $240 \mathrm{~mL}$ with $70 \%$ alcohol), in the absence of bright light, moderate shaking, and at room temperature. After 24 hours, extracts were filtered and the dry weight of 
the extract was calculated $(9.3 \mathrm{mg} / \mathrm{mL})$. The extract was placed in an amber bottle and kept refrigerated $[10,21]$.

2.2. Canine OSA Cells and spOS-2 Primary Culture. Dogs were subjected to physical examination, anamnesis, and complete clinical history at the Veterinary Hospital, FMVZ, UNESP, Campus of Botucatu. One dog with cytological OSA diagnosis was selected, and a primary culture of canine OSA cells was used [13]. The dog's owner was informed about the research and procedures and signed a free and enlightened consent Form. This work is in agreement with the Ethical Principles adopted by FMVZ, UNESP, Campus of Botucatu, Brazil (Protocol n. 98/2008).

Tumor fragments were harvested and cells were transferred to $25 \mathrm{~cm}^{2}$ flasks containing Dulbecco's Modified Eagle's Medium (DMEM), supplemented with 10\% fetal calf serum, penicillin $(100 \mathrm{UI} / \mathrm{mL})$, streptomycin $(100 \mu \mathrm{g} / \mathrm{mL})$, and amphotericin-B $(2.5 \mu \mathrm{g} / \mathrm{mL})$. Cells were incubated at $37^{\circ} \mathrm{C}$ and $5 \% \mathrm{CO}_{2}$. After confluence, cells were trypsinized and in vitro assays were carried out in triplicates.

spOS-2 primary cultures were isolated and characterized by biochemical and biomarker panels including alizarin red and by target proteins such as vimentin, cytokeratin, osteocalcin, osteopontin, osterix, and cyclo-oxygenase-2, using flow cytometry. Besides, Cox-2 was also evaluated by immunohistochemistry and divided into Cox-2 positive or Cox-2 negative cultures. Thus, spOS- 2 refers to a culture with upregulated Cox-2 expression.

2.3. Cytotoxicity Assay. After detachment from the flasks, cells were counted using a haemocytometer and cultivated in a 96-well U-bottomed plate (Corning) at a final concentration of $2 \times 10^{4}$ cells $/ \mathrm{mL}$, adding $100 \mu \mathrm{L} /$ well.

Geopropolis was diluted in DMEM medium, and specific dilutions were prepared for each assay in order to achieve $5,10,25,50$, and $100 \mu \mathrm{g}$. The same procedures were performed with $70 \%$ ethanol (geopropolis solvent), in order to obtain $0.03 ; 0.06 ; 0.15 ; 0.29$, and $0.59 \%$ alcohol, which were the respective concentrations of alcohol in geopropolis concentrations. As a positive control, carboplatin (100 and $200 \mu \mathrm{Mol} \cdot \mathrm{L}^{-1}$ ) was diluted in DMEM medium [22]. Control cells contained only the medium alone.

Cells were washed twice with PBS and incubated with each stimulus at $37^{\circ} \mathrm{C}$ and $5 \% \mathrm{CO}_{2}$ for $6,24,48$, and $72 \mathrm{~h}$. Cell viability was assessed over time.

2.4. Cell Viability. After each period of time, OSA cell morphology was evaluated microscopically, and cell viability was analyzed by violet crystal method as follows. Cells were incubated with $100 \mu \mathrm{L}$ violet crystal solution ( $0.2 \%$ diluted in $20 \%$ ethanol), which stains live cells. After $10 \mathrm{~min}$, cells were washed four times, and $100 \mu \mathrm{L}$ of $1 \%$ sodium dodecyl sulfate (SDS) was added. The optical density (O.D.) was read in an ELISA reader (Labsystems, Multiskan EX) at $492 \mathrm{~nm}$, and the percentages of cell viability were calculated [23].

2.5. Statistical Analysis. Friedman's test was used in order to analyze cell viability in the cultures for each geopropolis concentration according to the time period. Kruskal-Wallis test

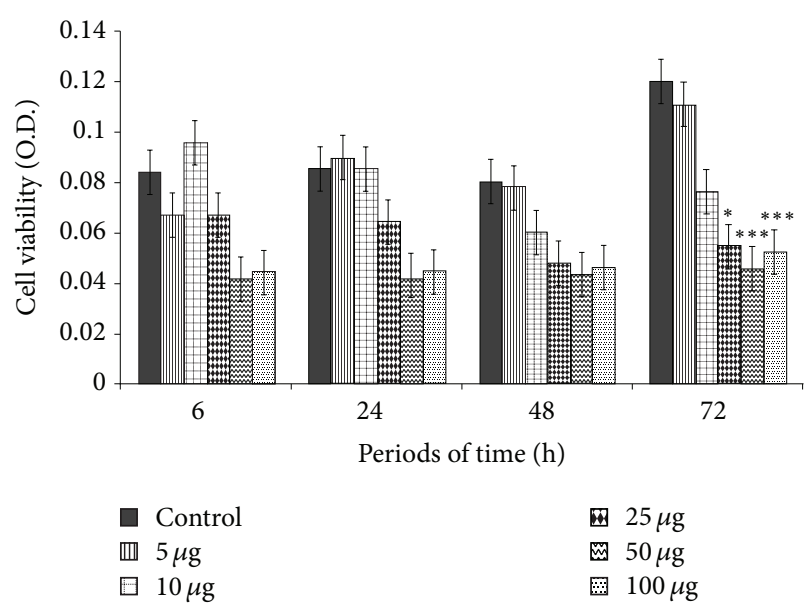

Figure 2: Canine OSA cell viability (optical density) according to geopropolis concentration $(5,10,25,50$, and $100 \mu \mathrm{g} /$ well) and periods of time $(6,24,48$, and $72 \mathrm{~h})$. Significantly different from the respective control $\left({ }^{*} \mathrm{P}<0.05 ;{ }^{* * *} \mathrm{P}<0.0001\right)$.

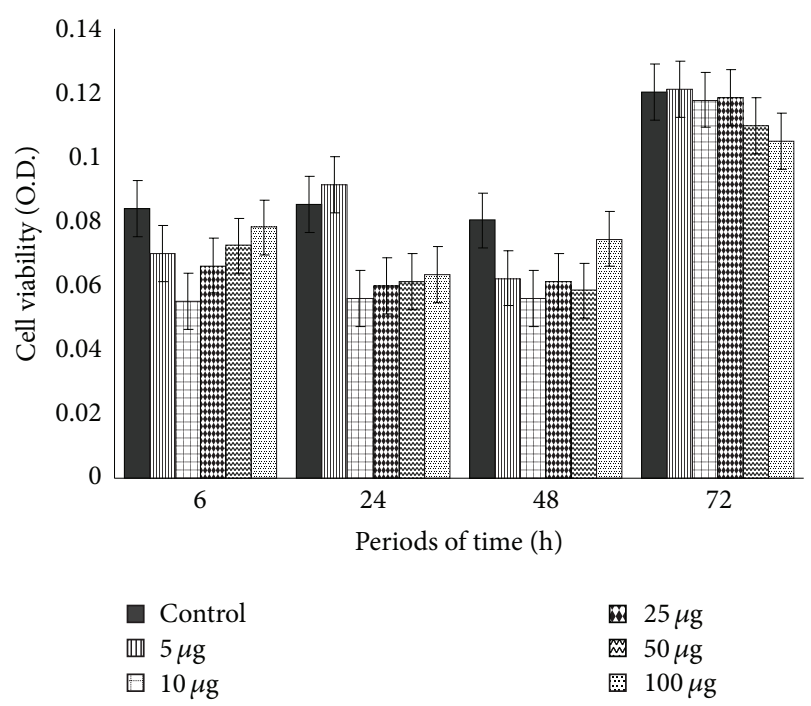

FIGURE 3: Canine OSA cell viability (optical density) after 6, 24, 48 , and $72 \mathrm{~h}$ of incubation with different concentrations of $70 \%$ ethanol corresponding to geopropolis concentrations $(5,10,25,50$, and $100 \mu \mathrm{g} /$ well $)(P>0.05)$.

was used to analyze the time period according to geopropolis concentrations. Statistical significances were accepted when $P<0.05$, and data represent three similar assays.

\section{Results}

3.1. OSA Cells Morphology. OSA cells are elongated, binucleated, or multinucleated polyhedral or pentagonal cells, showing cytoplasmic granules and vacuoles in most cells [24]. Geopropolis effect on OSA cells may be seen after 6 hours using $50 \mu \mathrm{g} /$ well (Figure 1(c)); 24 hours and $50 \mu \mathrm{g}$ (Figure 1(d)); 48 hours and $10 \mu \mathrm{g}$ (Figure 1(e)), and 72 hours and $10 \mu \mathrm{g}$ (Figure 1(f)), comparing to control (Figure 1(a)). 


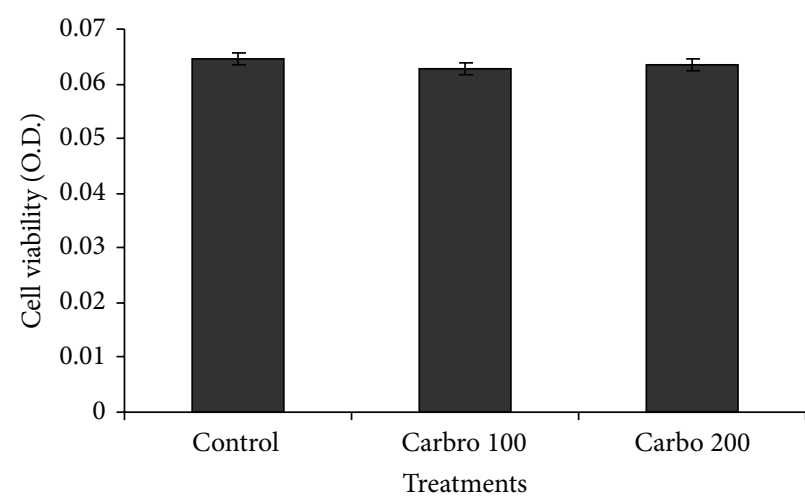

(a)

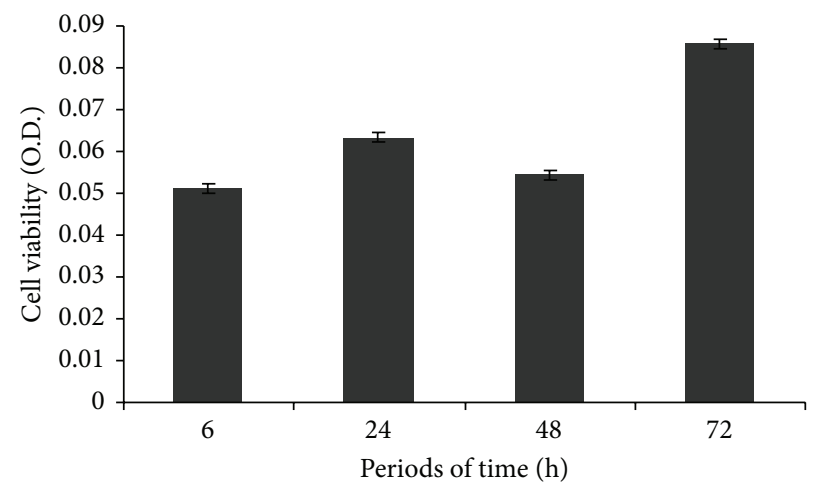

(b)

Figure 4: (a) Canine OSA cell viability (optical density) according to carboplatin concentration (carbo-100 and $200 \mu \mathrm{Mol} / \mathrm{L}$ ) and different periods of time (b) $(P>0.05)$.

$70 \%$ ethanol in different concentrations had no effect on OSA morphology (Figure 1(b)).

3.2. OSA Cells Viability. OSA cells were sensitive to geopropolis in the following periods of time: 6 hours and 50$100 \mu \mathrm{g} /$ well, $24 \mathrm{~h}$ with $50-100 \mu \mathrm{g}, 48 \mathrm{~h}$ with $10-100 \mu \mathrm{g}$, and $72 \mathrm{~h}$ with $10-100 \mu \mathrm{g}$, although nonsignificant. A significant decrease in cell viability was seen at $72 \mathrm{~h}$ using $25(P<0.05)$, 50, and $100 \mu \mathrm{g} /$ well $(P<0.0001)$ (Figure 2$) .70 \%$ alcohol showed no effect on cell cultures under study (Figure 3 ).

\subsection{Carboplatin Effect on OSA Cells Viability. Carboplatin} (100 and $200 \mu \mathrm{Mol} \cdot \mathrm{L}^{-1}$ ) had no effect over the periods of incubation of canine OSA cells with geopropolis $(P>0.05)$ in our assay conditions (Figure 4).

\section{Discussion}

Osteosarcoma is the primary bone tumor most frequently diagnosed in dogs, accounting for more than $80 \%$ of cases $[14,25]$, representing an excellent model in vivo to study human OSA, since its biology in dogs is similar to humans [15-17]. This type of cancer accounts for approximately $2 \%$ to $5 \%$ of all cancers in dogs and less than $1 \%$ in humans [26].

There have been a great number of researches dealing with propolis and tumor cells both in vitro and in vivo, using animal or humans models [11], indicating its potential for the development of new antitumor agents [5]. Nevertheless, little is known regarding geopropolis antitumoral activity.

In vivo and in vitro assays have been performed using hydroalcoholic extract of geopropolis produced by Melipona fasciculata on the development of Ehrlich ascitic tumor [7]. In vitro, geopropolis decreased the number of tumor cells after incubation with $500 \mu \mathrm{g} / \mathrm{mL}$ for $24 \mathrm{~h}$. In our assays, the cytotoxic action of geopropolis was achieved using $25 \mu \mathrm{g}$ after a longer period of incubation $(72 \mathrm{~h})$. Propolis produced by another stingless bee (Scaptotrigona sp.) was efficient against human glioblastoma (U251 and U343) [27].
In vivo, the pretreatment of mice with geopropolis $(50 \mathrm{mg} / \mathrm{kg})$ before the inoculation of tumor cells increased significantly the influx of macrophages into the peritoneal cavity and the release of hydrogen peroxide $\left(\mathrm{H}_{2} \mathrm{O}_{2}\right)$ and nitric oxide (NO) [7]. Moreover, geopropolis treatment inhibited the number of tumor cells and increased the survival of animals, suggesting that the antitumor effect of geopropolis may be related both to its direct tumoricidal effect and to its ability to recruit macrophages to the tumor focus, with a subsequent production of tumoricidal metabolites.

The effect of the hydroalcoholic extract of propolis produced by Scaptotrigona aff. postica was investigated on Ehrlich tumor development in female mice (a single dose $48 \mathrm{~h}$ prior to tumor inoculation) [28]. Propolis inhibited tumor development and increased the cell number in the spleen and bone marrow.

In our work, geopropolis exerted a cytotoxic effect on canine OSA cells, in a dose- and time-dependent manner, and the morphological analysis showed that osteosarcoma cells were sensitive to geopropolis in all periods of time. Its solvent (70\% ethanol) had no effect on cell viability, suggesting that the cytotoxic action was exclusively due to geopropolis. The chemical analysis of geopropolis by gas chromatographymass spectrometry (GC-MS) revealed that the main groups of compounds were pentoses, hexoses, sugar alcohols, uronic acids, disaccharides, alkylresorcinols, and triterpenes, which may be related to the anticancer effects of geopropolis on OSA cells.

Recently, we verified that propolis produced by Africanized honeybees affected OSA viability after $72 \mathrm{~h}$ compared to control, using $50 \mu \mathrm{g}$ and $100 \mu \mathrm{g} /$ well, in this same model. A comparison between these data showed that geopropolis was more efficient than propolis since the former had a cytotoxic action at lower concentrations [29]. Previous works of our laboratory reported propolis action on canine venereal transmissible tumor (TVT) [30] and on human laryngeal epidermoid carcinoma (HEp-2) cells [31]. It has been proposed that apoptosis and cell cycle arrest are the main mechanisms by which propolis affects the viability of tumor cells [11]. 
To date, no evidence of a possible mechanism of action of geopropolis has been proposed.

Carboplatin has been used as the main chemotherapeutic agent to treat canine OSA; nevertheless, it did not exert a cytotoxic effect in our assays. Three different osteosarcoma cell lines were investigated, showing that these lines were resistant to platinum chemotherapy [32]. Since the lines are monoclonal cell cultures, whose behavior in vitro exhibits a reduced aggression in relation to primary cultures [33], one may speculate that OSA culture showed a similar behavior to those resistant to carboplatin.

There are no works dealing with geopropolis and OSA, and our preliminary data point to a potential role of geopropolis in dogs with osteosarcoma, although further research should be carried out in vivo in order to evaluate its therapeutic action.

\section{Conflict of Interests}

No potential conflict of interests was disclosed.

\section{Acknowledgment}

This work was supported by Fundação de Amparo à Pesquisa do Estado de São Paulo (FAPESP-2009/53493-9).

\section{References}

[1] R. G. Woisky and A. Salatino, "Analysis of propolis: some parameters and procedures for chemical quality control," Journal of Apicultural Research, vol. 37, no. 2, pp. 99-105, 1998.

[2] V. Bankova, "Chemical diversity of propolis and the problem of standardization," Journal of Ethnopharmacology, vol. 100, no. 12, pp. 114-117, 2005.

[3] S. Castaldo and F. Capasso, "Propolis, an old remedy used in modern medicine," Fitoterapia, vol. 73, supplement 1, pp. S1-S6, 2002.

[4] F. A. Silveira, G. A. R. Melo, and E. A. B. Almeida, Abelhas brasileiras: sistemática e identificação, Composição e Arte, Belo Horizonte, Brazil, 2002.

[5] J. M. Sforcin and V. Bankova, "Propolis: is there a potential for the development of new drugs?" Journal of Ethnopharmacology, vol. 133, no. 2, pp. 253-260, 2011.

[6] S. A. D. C. Duailibe, A. G. Gonçalves, and F. J. M. Ahid, "Effect of a propolis extract on Streptococcus mutans counts in vivo," Journal of Applied Oral Science, vol. 15, no. 5, pp. 420-423, 2007.

[7] A. K. M. Assunção, Efeito antitumoral do tratamento profilático com extrato hidroalcóolico de geoprópolis de Melipona fasciculata Smith, Monografia (Graduação em Ciências Biológicas), Centro de Ciências Biológicas e da Saúde, Universidade Federal do Maranhão, São Luís, Brazil, 2008.

[8] J. L. Machado, Estudo das atividades anti-inflamatória e antinociceptiva do geoprópolis de Melipona fasciculata Smith (tiúba), Trabalho de Conclusão de Curso (Graduação em Farmácia), Universidade Federal do Maranhão, São Luís, Brazil, 2008.

[9] S. A. Libério, A. L. A. Pereira, R. P. Dutra et al., "Antimicrobial activity against oral pathogens and immunomodulatory effects and toxicity of geopropolis produced by the stingless bee Melipona fasciculata Smith," BMC Complementary and Alternative Medicine, vol. 11, article 108, 2011.

[10] R. P. Dutra, A. M. C. Nogueira, R. R. O. Marques, M. C. P. Costa, and M. N. S. Ribeiro, "Avaliação farmacognóstica de geoprópolis de Melipona fasciculata Smith da Baixada Maranhense, Brasil," Revista Brasileira de Farmacognosia, vol. 18, pp. 557-562, 2008.

[11] J. M. Sforcin, "Propolis and the immune system: a review," Journal of Ethnopharmacology, vol. 113, no. 1, pp. 1-14, 2007.

[12] S. J. Withrow, "Tumor of the skeletal system," in Small Animal Clinical Oncology, S. J. Withrow and E. G. MacEwen, Eds., pp. 1-3, Saunders, Philadelphia, Pa, USA, 3rd edition, 2001.

[13] K. G. Thompson and R. R. Pool, “Tumors of bones," in Tumors in Domestic Animals, D. J. Meuten, Ed., pp. 245-317, Iowa State Press, Ames, Iowa, USA, 4th edition, 2002.

[14] B. Wolfesberger, I. Walter, C. Hoelzl, J. G. Thalhammer, and M. Egerbacher, "Antineoplastic effect of the cyclooxygenase inhibitor meloxicam on canine osteosarcoma cells," Research in Veterinary Science, vol. 80, no. 3, pp. 308-316, 2006.

[15] C. Khanna, J. Khan, P. Nguyen et al., "Metastasis-associated differences in gene expression in a murine model of osteosarcoma," Cancer Research, vol. 61, no. 9, pp. 3750-3759, 2001.

[16] J. Kirpensteijn, E. P. M. Timmermans-Sprang, E. van Garderen, G. R. Rutteman, I. S. Lantinga-van Leeuwen, and J. A. Mol, "Growth hormone gene expression in canine normal growth plates and spontaneous osteosarcoma," Molecular and Cellular Endocrinology, vol. 197, no. 1-2, pp. 179-185, 2002.

[17] M. N. Mullins, S. E. Lana, W. S. Dernell, G. K. Ogilvie, S. J. Withrow, and E. J. Ehrhart, "Cyclooxygenase-2 expression in canine appendicular osteosarcomas," Journal of Veterinary Internal Medicine, vol. 18, no. 6, pp. 859-865, 2004.

[18] C. S. Fonseca, C. R. Daleck, and L. Repetti, "Terapias sistêmicas em oncologia veterinária," Nosso Clínico-Medicina Veterinária Para Animais de Companhia, vol. 30, pp. 28-38, 2002.

[19] D. Larone and C. Delprat, Quimioterapia Anticancerígena, Roca, 1st edition, 2004.

[20] E. G. Moura, Agroambientes de transição: entre o trópico úmido e o semi-árido do Brasil, UEMA, São Luís, Brazil, 2004.

[21] B. V. B. Abreu, M. C. A. Batista, C. C. Azevedo et al., "Quantificação de polifenois de geoprópolis de Melipona fasciculata Smith (tiúba) coletado no cerrado maranhense," Revista Ciências da Saúde, vol. 8, pp. 18-24, 2006.

[22] P. A. Konstantinopoulos, E. Fountzilas, K. Pillay et al., "Carboplatin-induced gene expression changes in vitro are prognostic of survival in epithelial ovarian," BMC Medical Genomics, vol. 1, article 59, 2008.

[23] L. A. Mbarek, H. A. Mouse, N. Elabbadi et al., "Anti-tumor properties of blackseed (Nigella sativa L.) extracts," Brazilian Journal of Medical and Biological Research, vol. 40, no. 6, pp. 839-847, 2007.

[24] P. Loukopoulos, T. O'Brien, M. Ghoddusi, B. A. Mungall, and W. F. Robinson, "Characterisation of three novel canine osteosarcoma cell lines producing high levels of matrix metalloproteinases," Research in Veterinary Science, vol. 77, no. 2, pp. 131-141, 2004.

[25] A. S. Hammer, F. R. Weeren, S. E. Weisbrode, and S. L. Padgett, "Prognostic factors in dogs with osteosarcomas of the flat or irregular bones.", Journal of the American Animal Hospital Association, vol. 31, no. 4, pp. 321-326, 1995.

[26] R. Gorlick and C. Khanna, "Osteosarcoma," Journal of Bone and Mineral Research, vol. 25, pp. 683-691, 2010. 
[27] K. S. Borges, M. S. Brassesco, C. A. Scrideli, A. E. E. Soares, and L. G. Tone, "Antiproliferative effects of Tubi-bee propolis in glioblastoma cell lines," Genetics and Molecular Biology, vol. 34, no. 2, pp. 310-314, 2011.

[28] M. J. A. M. Araújo, R. P. Dutra, G. C. Costa et al., "Efeito do tratamento com própolis de Scaptotrigona aff. postica sobre o desenvolvimento do tumor de Ehrlich em camundongos," Revista Brasileira de Farmacognosia, vol. 20, pp. 580-587, 2010.

[29] N. C. Cinegaglia, P. R. O. Bersano, M. C. Búfalo, and J. M. Sforcin, "Cytotoxic action of Brazilian propolis in vitro on canine osteosarcoma cells," Phytotherapy Research, 2012.

[30] S. Bassani-Silva, J. M. Sforcin, A. S. Amaral, L. F. J. Gaspar, and N. S. Rocha, "Propolis effect in vitro on canine transmissible venereal tumor cells," Revista Portuguesa de Ciências Veterinárias, vol. 102, pp. 261-265, 2007.

[31] M. C. Búfalo, J. M. G. Candeias, and J. M. Sforcin, "In vitro cytotoxic effect of Brazilian green propolis on human laryngeal epidermoid carcinoma (HEp-2) cells," Evidence-Based Complementary and Alternative Medicine, vol. 6, no. 4, pp. 483487, 2009.

[32] H. Robson, S. Meyer, S. M. Shalet, E. Anderson, S. Roberts, and O. B. Eden, "Platinum agents in the treatment of osteosarcoma: efficacy of cisplatin versus carboplatin in human osteosarcoma cell lines," Medical and Pediatric Oncology, vol. 39, no. 6, pp. 573-580, 2002.

[33] R. I. Freshney, Culture of Animals Cells, John Wiley \& Sons, Hoboken, NJ, USA, 6th edition, 2010. 


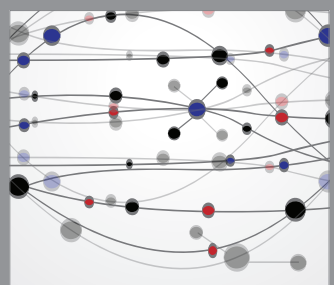

The Scientific World Journal
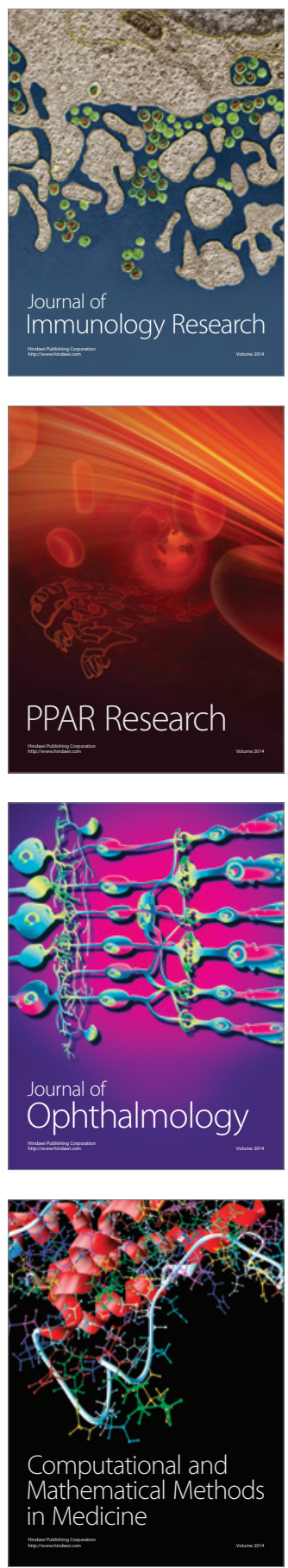

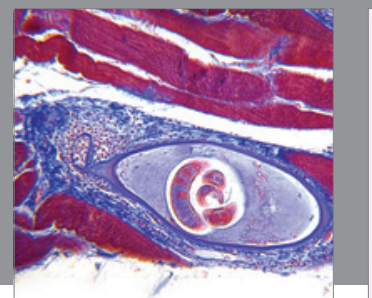

Gastroenterology

Research and Practice
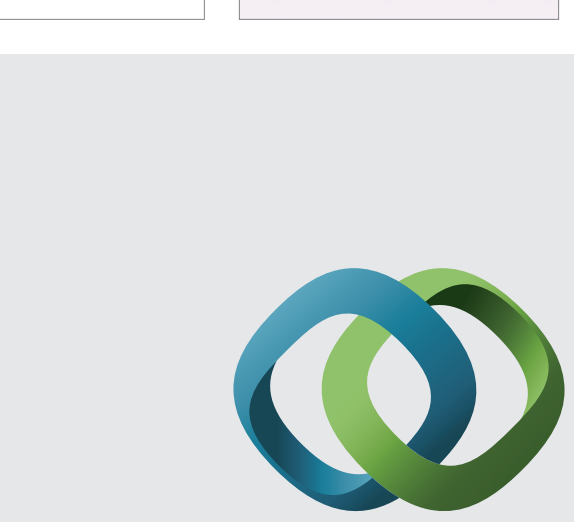

\section{Hindawi}

Submit your manuscripts at

http://www.hindawi.com
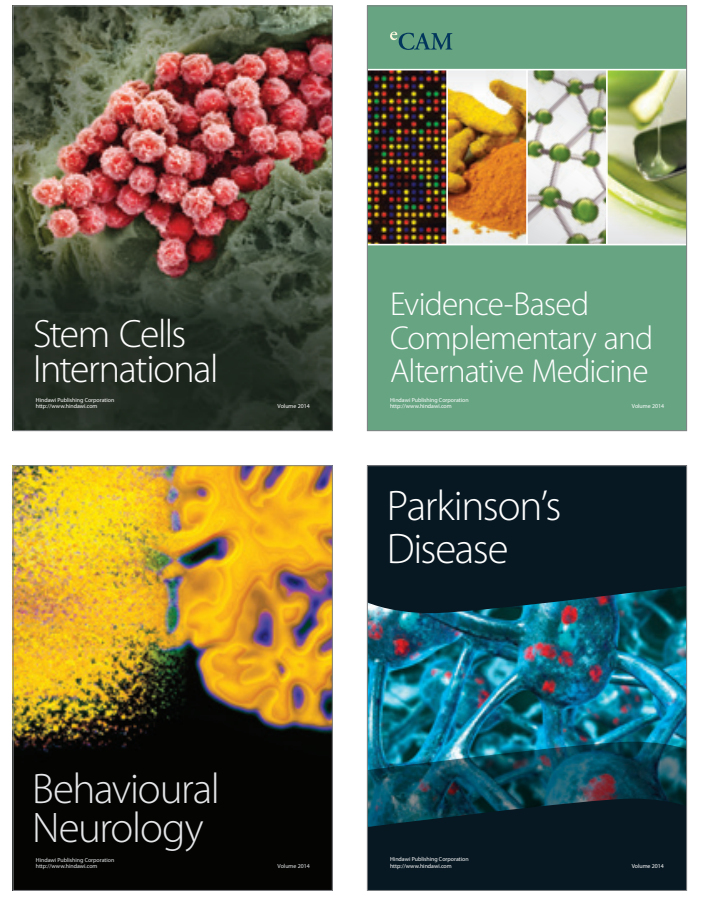
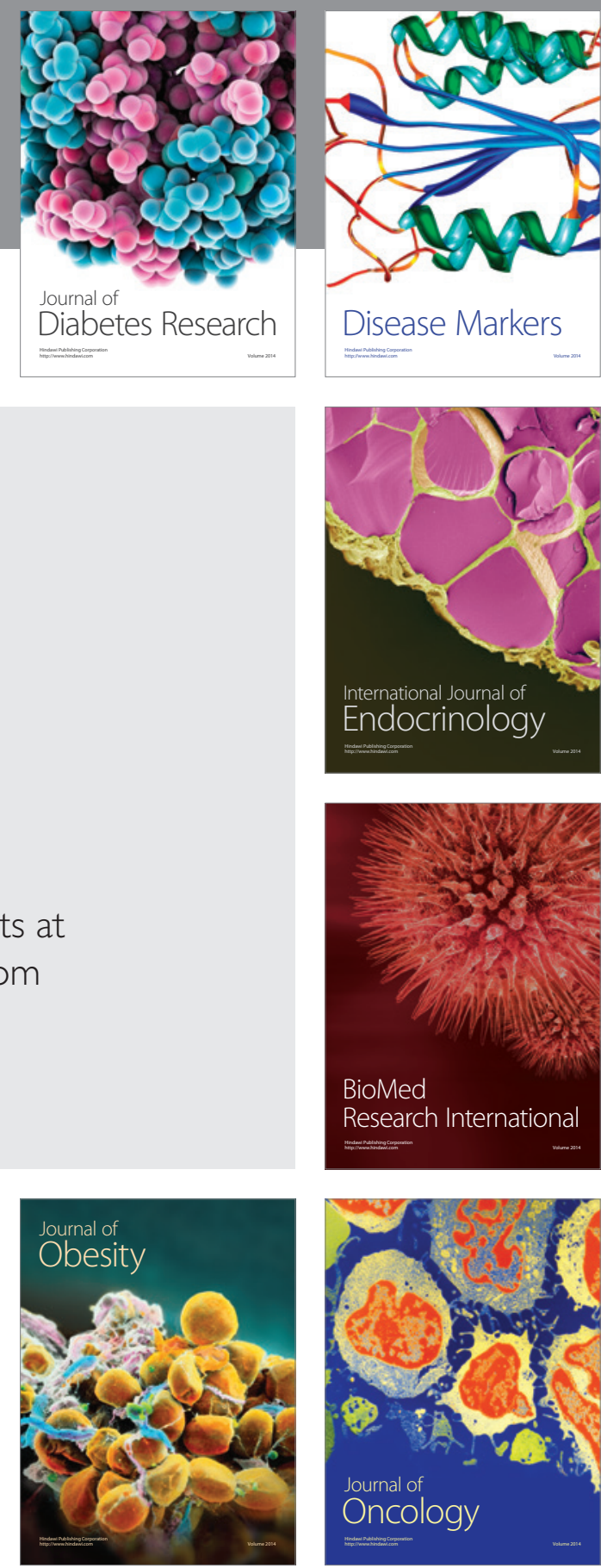

Disease Markers
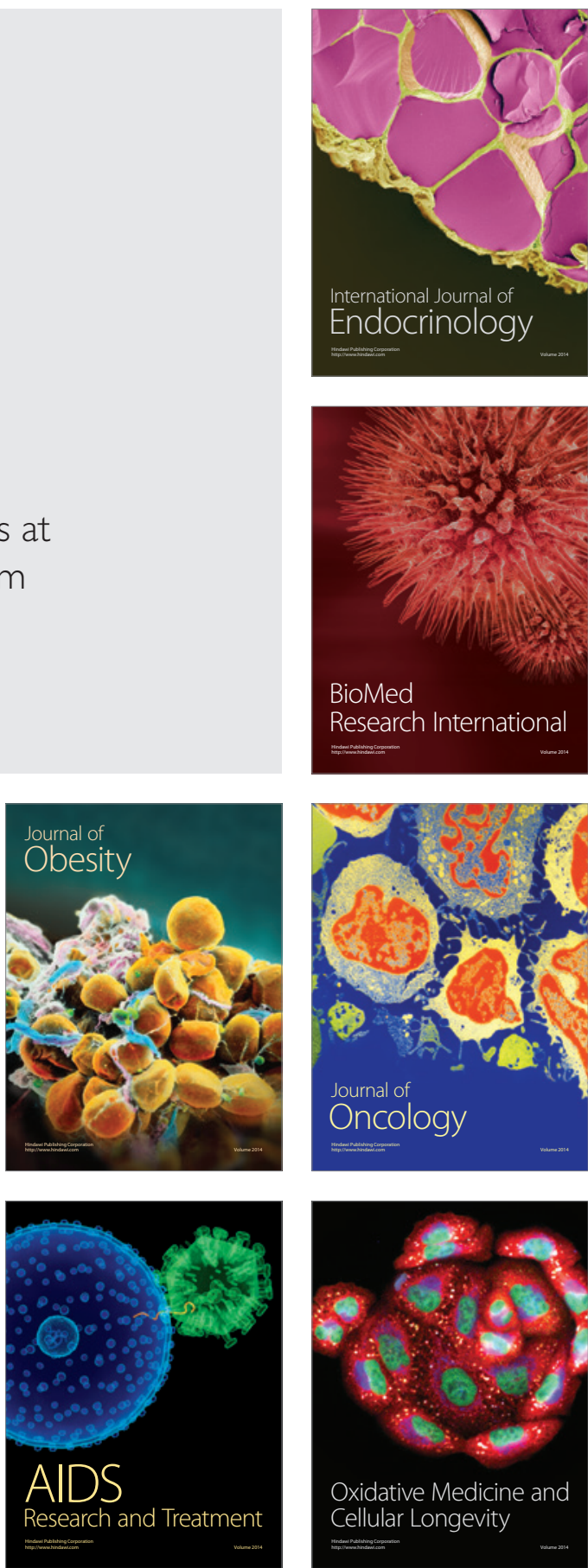